\title{
XXIX. A suggested theory of the aluminium anode
}

\author{
W.W. Taylor M.A. D.Sc. \& J.K.H. Inglis M.A. B.Sc.
}

To cite this article: W.W. Taylor M.A. D.Sc. \& J.K.H. Inglis M.A. B.Sc. (1903) XXIX. A suggested theory of the aluminium anode , Philosophical Magazine Series 6, 5:27, 301-313, DOI: 10.1080/14786440309462927

To link to this article: http://dx.doi.org/10.1080/14786440309462927

$$
\text { 曲 Published online: } 15 \text { Apr } 2009 .
$$

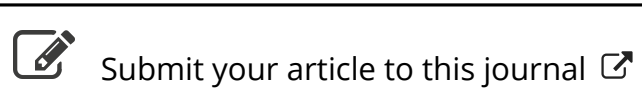

\section{Џ Article views: 4}

Q View related articles $₫$

4 Citing articles: 7 View citing articles 준 
A Suggested Theory of the Aluminium Anode.

301

manner (22) must be incapable of stimulating a motion similar to $v=\cos y$. The necessary conditions are

$$
\begin{aligned}
& \iint \cos x\left\{\left(\sigma-\sigma_{0}\right) \cos x \mp 2 n \cos y\right\} d x d y=0, \\
& \iint \cos y\left\{\left(\sigma-\sigma_{0}\right) \cos y \mp 2 n \cos x\right\} d x d y=0,
\end{aligned}
$$

the integration being taken over the whole area. On account of the symmetry the two conditions coincide; and it is sufficient to integrate for $x$ and $y$ between the limits 0 and $\frac{1}{2} \pi$. Thus

so that

$$
\left(\sigma-\sigma_{0}\right) \cdot \frac{1}{2} \pi \cdot \frac{1}{4} \pi= \pm 2 n \cdot 1 \cdot 1,
$$

$$
\sigma-\sigma_{0}= \pm \frac{16 n}{\pi^{2}} . \cdots . .
$$

Since $n$ and $\sigma$ are of the same dimensions, this result holds good, whatever may be the side of the square.

It may be of interest, and serve as a confirmation of the above procedure, to mention that when applied to the principal vibration in a rotating circular trough it gives

$$
\sigma-\sigma_{0}= \pm \frac{2 n}{z_{1}^{2}-1}, \quad \text {. . . . . . . }
$$

where $z_{1}$ is the first root of $J_{1}^{\prime}(z)=0$, equal to $1 \cdot 841$, so that

$$
\sigma-\sigma_{0}= \pm \frac{2 n}{2 \cdot 38}
$$

An accordant result may be deduced from the analysis given by Lamb, $\S 203$, by putting $s=1$, and taking account of the properties of the function $J_{1}$. The corresponding value of $\zeta$ is given by

$$
\zeta=e^{i \sigma t} J_{1}(k r)\{\cos \theta+i \sin \theta\} . \quad \text {. . . . }
$$

XXIX. A Suggested Theory of the Aluminium Anode. By W. W. TAYLOR, M.A., D.Se., and J. K. H. IngLis, M.A., B.Se.*

LTHOUGH aluminium is one of the metals which de-
sulphuric acid, even at moderately high temperatures. With
dilute hydrochloric acid the action is violent, and it is found
that, if a little hydrochloric acid or soluble chloride $(e . g$. ,
potassium chloride) be added to dilate sulphuric acid, the action
is, to all appearance, as violent as with hydrochloric acid of
similar concentration.

* Communicated by the Physical Society : read November 14th, 1902. 
The primary object of this investigation was to find an explanation of this anomalous behaviour of sulphuric acid, and of the effect produced by the addition of chloride. It has long been known * that, when an aluminium electrode is employed as anode in a solution of a sulphate or of sulphuric acid, there is a very great resistance offered to the current, and that this resistance is due to a film which separates the electrode from the solution. If the aluminium is the cathode, or if other acids are substituted for sulphuric acid, this great resistance does not exist. The film cannot merely act as a dead resistance, for the resistance is different according to the direction of the current. It seems probable, then, that the two phenomena are related, and that the film is also the cause of the slow action of sulphuric acid on aluminium. This paper is an attempt to find an explanation which will satisfactorily account for all these phenomena.

\section{Historical Summary.}

The behaviour of aluminium as anode in dilute sulphuric acid has been the subject of many investigations, but they have been mainly directed to proving the existence of the abnormalities, and not to finding the cause of them. The earliest measurements appear to have been made by Wheatstone $\dagger$, who tried to ascertain the position of aluminium in the voltaic series. He found that its position depended on the electrolyte used, and he noticed especially the slight action of nitric acid and of sulphuric acid, and the small current obtained with the latter acid. His experiments were repeated in greater detail by Buff $\ddagger$, who observed remarkable peculiarities with dilute sulphuric acid as the electrolyte. He found on electrolysis of dilute sulphuric acid with an aluminium anode and an external battery, that the anode became covered with a dark skin which he supposed to be silicon. Tait $\S$ investigated the polarization of the aluminium cell, using a variable polarizing battery. If six Grove's cells formed the polarizing battery, the reverse E.M.F. was $5 \cdot 20$ Daniells ; in this case the polarizing E.M.F. was $10 \cdot 44 \mathrm{D}$. As his measurements were made with a Thomson electrometer, they were independent of resistance.

The dark skin first observed by Buff was the subject of several investigations made by Beetz $\|$. He at first supposed

* Buff, Liebig's Annalen, cii. p. 269 (1857).

+ Phil. Mag. [4] x. p. 143 (1854).

Loc. cit.

§ Phil. Mag. [4] xxxviii. p. 243 (1869).

II Pogg. Annalen, vol. cxxvii. p. 45 ; vol. clvi. p. $464 ; 1877$, vol. ii. p. 94 . 
it to be an aluminium suboxide; but, later, came to the conclusion that it is merely the ordinary oxide or hydroxide. More recently Norden * showed that the film is the ordinary hydroxide, Al $(\mathrm{OH})_{3}$. Lawrie $\uparrow$ had previously come to the conclusion, based on experiments upon the effect of amalgamation on the electrochemical behaviour of aluminium, that the peculiarities are due to a layer of oxide or of suboxide.

The subject has also been investigated by several physicists who endeavoured to explain the physical peculiarities. At first the film of oxide was supposed to act as a layer which protected the electrode from the action of the electrolyte; but Oberbeck $\ddagger$ and Streintz $\S$ suggested that the film acts as a non-conductor, and that the electrode, the film, and the electrolyte form a condenser ; and a condenser consisting of two aluminium plates with a solution of a sulphate as electrolyte has been described by Haagn $\|$. In all these cases a neutral sulphate or sulphuric acid solution formed the electrolyte, Streintz especially mentioning that in nitric acid the behaviour of aluminium is quite normal. The question became one of practical importance when Pollak $\mathbb{I}$ and Grätz ** independently showed that a cell consisting of one aluminium electrode and one carbon electrode in dilute sulphuric acid could be used to change an alternating current into a direct current, since the phase in which aluminium is the anode is stopped by the cell. Various investigators $\dagger \dagger$ found that currents of 20 volts or even of 100 volts potential can be so transformed. Later researches have not brought to light many new facts, though Wilson $\ddagger \ddagger$ showed that the transformation is not complete if the period of alternation is less than $\frac{7}{16}$ second. None of the investigators attempt to explain how this film is produced and maintained. Norden $\S \S$. however, gives the following explanation:-When sulphuric acid is electrolysed with an aluminium anode the secondary oxygen produced acts on the anode to form $\mathrm{Al}(\mathrm{OH})_{3}$, which

* Keit. fiir Elektrochemie, vi. pp. 159, 188 (1899-1900).

+ Phil. Mag. [5] xxii. p. 213 (1886).

$\ddagger$ Wied. Ann. xix. p. 625 (1883).

\$ Wied. Ann. xxxii. p. 116 (1887); xxxiv. p. 751 (1888).

II Keit. für Elektrochemie, iii. p. 470 (1896-97).

T Compt. Rend. cxxiv, p. 1443 (1897).

*** Wied. Ann. lxii. p. 323 (1897).

+ Bleiblätter, xxiii. pp. 108, 502, 564, 650; Elektrotechn. Zeits. xxi. p. 913.

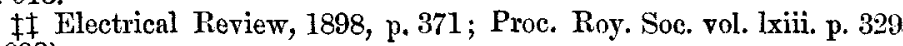
(1898).

$\$ \S$ Loc. cit. 
is slowly dissolved by the sulphuric acid or by the aluminium sulphate already in solution, and thus the film is continually renewed on one side and dissolved on the other. If hydrochloric acid be used as electrolyte, the free chlorine acts on the aluminium and forms a soluble salt $\mathrm{AlCl}_{3}$, and not a difficultly soluble oxide.-This explanation is hardly sufficient, for no reasons are given for the formation of secondary oxygen ; and, further, aluminium sulphate is a fairly soluble salt. Hence a full explanation is still wanting.

\section{Experimental Results.}

Experiments were made, in the first instance, to ascertain in what way the addition of certain salts to the electrolyte affected the aluminium anode. For this purpose the 12 volt storagebattery of the laboratory was used, and in the circuit were a $3 \mathrm{ohm}$ (approximate) resistance, an ammeter which could be read to 0.01 ampere and up to 3.0 amperes, and the electrolytic cell, all in series; a voltmeter reading to 0.05 volt and up to $15 \cdot 0$ volts was also in parallel circuit with the cell. The cell consisted of a beaker containing a 1/1 molar solution of sulphuric acid and the two electrodes, the one of sheetaluminium, and the other a spiral of thick platinum wire. The procedure was as follows :-The circuit was closed, with the acid alone as electrolyte, and the readings of the voltmeter and ammeter noted as soon as they became constant. To the acid were added successive small quantities of a solution of the salt under investigation; and, after closing the circuit, readings were noted every few minutes until they again became constant. It was found necessary to use a fresh piece of aluminium each time, as, through the continued action of the weak current, the film on the anode became so thick and resisting that addition of even large quantities of potassium chloride had no influence on the current, although a small quantity only was required when a fresh surface was taken. It was therefore necessary to have the surface in as uniform a condition as possible in order that the experiments should be comparable, and this was most easily ensured by using a fresh surface each time.

Elfect of Chloride and of Bromide.-The results are given in the following tables.

In the case of ammonium alum solution (Table I.) the effect of potassium bromide was also determined, and after addition of 0.3 c.c. of a 4 molar $\mathrm{KBr}$ solution, the current passed freely, though it did not increase so rapidly as after addition of chloride. 


\section{TABLe I.}

Solution of $\mathrm{H}_{2} \mathrm{SO}_{4}=1$ molar.

$. \quad \mathrm{KCl}=3.9$ molar (saturated).

\begin{tabular}{|c|c|c|c|}
\hline $\begin{array}{l}\text { Voltmeter in } \\
\text { open circuit. }\end{array}$ & Electrolyte. & $\begin{array}{l}\text { Voltmeter in } \\
\text { closed circuit. }\end{array}$ & $\begin{array}{l}\text { Current in } \\
\text { Amperes. }\end{array}$ \\
\hline $11 \cdot 7$ volt. & $\begin{array}{cc}25 \text { c.c. } \mathrm{H}_{2} \mathrm{SO}_{4} \ldots \ldots \ldots \ldots \ldots \ldots \\
, " & +0.19 \text { c.c. } \mathrm{KOl} \\
, " & +0.5 \text { c.c. } \mathrm{KOl} \\
, & +0.33 \text { c.c. } \mathrm{KCl} .\end{array}$ & $\begin{array}{c}11 \cdot 6 \\
11 \cdot 6 \\
11 \cdot 6 \\
11 \cdot 6 \\
\text { falling rapidly } \\
\text { to } 7 \cdot 1\end{array}$ & $\begin{array}{c}0.01 \\
0.02 \\
0.02 \\
0.03 \\
\text { rising to } \\
\mathbf{1} \cdot 50\end{array}$ \\
\hline $11 \cdot 7$ volt. & $\begin{array}{r}25 \text { c.c. saturated ammonium } \\
\text { alum solution..... } \\
\quad, \quad, \quad+0.27 \text { c.c. KOI. }\end{array}$ & $\begin{array}{r}11 \cdot 6 \\
9 \cdot 4\end{array}$ & $\begin{array}{r}<0.01 \\
0.76\end{array}$ \\
\hline
\end{tabular}

The experiments were then repeated with more dilute solutions of chloride and bromide.

\section{TABLe II.}

Solution of $\mathrm{H}_{2} \mathrm{SO}_{4}=1$ molar.

,$\quad \mathrm{KCl}=0.39$ molar.

\begin{tabular}{|c|c|c|c|}
\hline $\begin{array}{l}\text { Voltmeter in } \\
\text { open circuit. }\end{array}$ & Electrolyte. & $\begin{array}{l}\text { Voltmeter in } \\
\text { closed circuit. }\end{array}$ & $\begin{array}{c}\text { Current in } \\
\text { Amperes. }\end{array}$ \\
\hline 11.7 volt. & 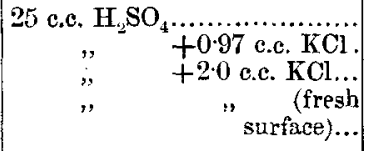 & $\begin{array}{c}11 \cdot 65 \\
11 \cdot 65 \\
\text { falling to } 7 \cdot 0\end{array}$ & $\begin{array}{l}\quad \begin{array}{l}0.01 \\
0.01\end{array} \\
\text { rising to } 0.50 \\
\text { rising to } 0.80\end{array}$ \\
\hline $11 \cdot 7$ volt. & 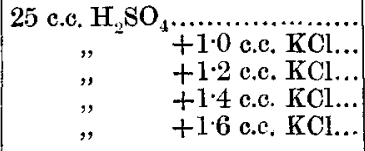 & $\begin{array}{l}11 \cdot 65 \\
11 \cdot 60 \\
11 \cdot 60 \\
11 \cdot 60 \\
\cdots \cdots\end{array}$ & $\begin{array}{l}<0.01 \\
0.025 \text { (rising) } \\
0.02 \text { (rising) } \\
0.02 \text { (rising) } \\
1.0\end{array}$ \\
\hline
\end{tabular}

In the second of these experiments the currents rose at once to 1.0 ampere atter addition of 1.6 c.c. $\mathrm{KCl}$ solution, but with smaller concentrations of chloride the current was rather variable, as if the resistance of the film was continually changing. In the case of bromide the current did not increase until 5.0 c.c. of a 0.4 molar $\mathrm{KBr}$ solution had been added. It then rose steadily to 0.5 ampere, but the increase was not so rapid as with chloride. 
Similar experiments were made with other salts, and the results may be very briefly described.

Nitrate.-A $2 \cdot 6$ molar solution of potassium nitrate was used. After addition of $3 \cdot 0$ c.c. of the solution to 25 c.c. of acid, the current at once rose steadily ; considerable irregularity was shown after addition of $2 \cdot 0$ c.c. of the nitrate solution.

Acetate.-Addition of sodium acetate to sulphuric acid had no effect. In order to attain a considerable concentration of acetions, a saturated solution of sodium sulphate was then used instead of sulphuric acid, but this made no difference.

Thiocyanate.-A $2 \cdot 0$ molar solution of potassium thiocyanate was used. Addition of 2.0 to 3.0 c.c. of the solution was found necessary to enable the current to pass readily.

Chlorate.-Addition of potassium chlorate was also found to enable the current to pass readily.

As the presence of aluminium salt might, conceivably, influence the results, several of the above experiments were repeated after 1.0 c.c. of 0.5 molar aluminium sulphate solution had been added to the acid, but no differences were found.

These experiments show that the presence of certain ions, even in small concentration, enables a large current to pass through the cell ; and it seemed to us probable that the reason is that the film of aluminium hydroxide with which the anode is covered is permeable to certain ions, but impermeable to others*. If this is so, any anion which can readily pass through the film will enable a current to pass, whilst anions which cannot readily pass through will not enable it to do so. The anomalous behaviour in sulphuric acid would then be due to the impermeability of the film to $\mathrm{SO}_{4}{ }^{\prime \prime}$ ions, and also to $\mathrm{Al} \cdots$ ions. This explanation is also in accord with the fact that reversal of the current immediately causes a current to pass through the cell, this being due to the permeability of the film to $\mathrm{H}$ ions, for it is difficult to suppose that reversal of the current immediately removes the film and subsequent reversal immediately restores it.

We next made a series of experiments to determine the relative rates of diffusion of these ions through a film of aluminium bydroxide. The method adopted is one devised by Walden $f$ and consists in forming a film of gelatine containing ammonium chromate over one end of a glass tube, exposing it to daylight, and then washing out all soluble

* Cf Ostwald, Zeit. f. Phys. Chem. vi. p 71 (1890).

† Zeit.f. Physik Chem. x. p. 699 (1892). 
substances. The tube is then placed in a solution of aluminium salt, and ammonia solution is put inside the tube. In this way a film of $\mathrm{Al}(\mathrm{OH})_{3}$ is formed where the two solutions meet, i.e., in the interior of the gelatine. A solution of the salt under examination is then added to the ammonia solution in the inner tube, and from time to time the outer solution is tested for the salt. From the fact that a film of aluminium hydroxide can be formed in this way, one may conclude that it is impermeable to $\mathrm{Al} \cdots$ ions, and to $\mathrm{OH}^{\prime}$ ions, as otherwise diffusion would continue until one or other of the salts was completely removed.

Having set up a large number of cells we found that $\mathrm{KCl}$, $\mathrm{KBr}, \mathrm{KNO}_{3}, \mathrm{KClO}_{3}$, and $\mathrm{KCNS}$ all diffuse through rapidly, though not equally so; $\mathrm{NaC}_{2} \mathrm{H}_{3} \mathrm{O}_{2}$ diffuses slowly, and $\mathrm{K}_{2} \mathrm{SO}_{4}$ only to a very slight extent. To confirm this result, more cells were set up, and mixtures of $\mathrm{KCl}$ and $\mathrm{K}_{2} \mathrm{SO}_{4}$, $\mathrm{KBr}$ and $\mathrm{K}_{2} \mathrm{SO}_{4}$, were added to the ammonia solution, so that the rates of diffusion through the same film could be observed. The same results were obtained.

It now seemed very probable that the abnormal behaviour of the aluminium anode in sulphuric acid was due to this impermeability. According to Ditte *, the surface of aluminium is covered with a thin film of hydroxide which preserves it from the further action of the air. If, therefore, a piece of aluminium be, made the anode in dilute sulphuric acid, the $\mathrm{SO}_{4}{ }^{\prime \prime}$ ions are unable to pass from the solution through the film to the anode, and similarly $\mathrm{Al} \cdots$ ions are unable to pass from the anode into the solution. Hence there are no ions to carry the electricity through the film, and no current can pass. A very slight current does pass, and this may be due to $\mathrm{Al} \cdots$ ions being formed at the anode, $\mathrm{H} \cdot$ ions of the water passing at the same time through the film and thus leaving $\mathrm{OH}^{\prime}$ ions which form $\mathrm{Al}(\mathrm{OH})_{\text {s }}$ with the $\mathrm{Al} \cdots$ ions just formed. This aluminium hydroxide replaces that which may be removed by solution in the acid, and in this way the continuity of the film is maintained.

If $\mathrm{Cl}^{\prime}, \mathrm{Br}^{\prime}$, or $\mathrm{NO}_{3}^{\prime}$ ions are present, they can migrate through the film, thus carrying electricity to the anode where they unite with $\mathrm{Al} \cdots$ and form neutral salts; and this formation of salt behind the film will break it loose, and so enable the current to pass easily. In this way the results obtained admit of an easy and rational explanation.

If this explanation is correct, it should be possible to * Compt. Rend. cxxvii. p. 919 (1898). 
reproduce the peculiarities of the aluminium electrode with a platinum electrode and a film of aluminium hydroxide. There are various ways in which this might be done, but for practical reasons the following was adopted. The cell consisted of two large pieces of platinum foil as electrodes, an inner porous cell containing ammonia solution $(1$ molar) and an outer glass beaker containing altuminium sulphate solution $\left(\frac{1}{6}\right.$ molar). In this way a film of aluminium hydroxide was deposited in the wall of the porous cell.

If the aluminium sulphate solution contained the anode, no current should pass, since $\mathrm{Al} \cdots$ ions cannot migrate through the film to the cathode, nor $\mathrm{OH}^{\prime}$ ions to the anode. Addition of $\mathrm{SO}_{4}^{\prime \prime}$ ions to the ammonia should have no effect on the current, but addition of $\mathrm{Cl}^{\prime}$ ions should cause a current to pass. Reversal of the poles, also, should cause a current to pass, for $\mathrm{NH}_{4}{ }^{\circ}$ ions can readily pass through the film. With such a cell, and with the 12-volt storage-battery and the same arrangement of apparatus as already described, the following results were obtained :-

\begin{tabular}{|c|c|c|c|}
\hline $\begin{array}{l}\text { Aluininium } \\
\text { sulphate solution } \\
\text { contained : }\end{array}$ & $\begin{array}{l}\text { Time from } \\
\text { closing circuit } \\
\text { (minutes). }\end{array}$ & Voltmeter. & Ammeter. \\
\hline Anode. & $\begin{array}{r}0 \\
60 \\
1140\end{array}$ & $\begin{array}{l}11 \cdot 6 \\
12 \cdot 0 \\
12 \cdot 0\end{array}$ & $\begin{array}{l}0.20 \\
0.07 \\
0.03\end{array}$ \\
\hline Cathode. & $\underset{45}{\text { immediately. }}$ & $\begin{array}{l}11 \cdot 2 \\
10 \cdot 4\end{array}$ & $\begin{array}{l}0 \cdot 20 \\
0 \cdot 41\end{array}$ \\
\hline Anode. & $\begin{array}{r}10 \\
180\end{array}$ & $\begin{array}{l}11 \cdot 7 \\
11.95\end{array}$ & $\begin{array}{l}0 \cdot 10 \\
0.03\end{array}$ \\
\hline Cathode. & 15 & $10 \cdot 8$ & 0.43 \\
\hline $\begin{array}{l}\text { Inode. } \\
\text { Anode. }\end{array}$ & $\begin{array}{c}6 \\
\text { immediately. } \\
4 \\
20\end{array}$ & $\begin{array}{c}11 \cdot 7 \\
(50 \text { volt eurrent } \\
\text { used.) } \\
", \\
",\end{array}$ & $\begin{array}{l}0.13 \\
0.22 \\
0.07 \\
0.04\end{array}$ \\
\hline Cathode. & immediately. & (50 volts.) & $(42$ ohms in circuit. $)$ \\
\hline
\end{tabular}

The small current which passes is due to the low conductivity of ammonia solution; so a similar experiment was made with a solution of sodium carbonate in the porous cell, as sodium hydroxide might act on the film. The only difference found was that the maximum current was much greater. 


\begin{tabular}{|c|c|c|c|}
\hline $\begin{array}{l}\text { Aluminium } \\
\text { sulpbate solution } \\
\text { contained : }\end{array}$ & $\begin{array}{l}\text { Time from } \\
\text { closing circuit } \\
\text { (minutes). }\end{array}$ & Voltmeter. & Ammeter. \\
\hline Anode. & $\begin{array}{r}0 \\
13 \\
65\end{array}$ & $\begin{array}{l}11 \cdot 3 \\
11 \cdot 8 \\
11.95\end{array}$ & $\begin{array}{l}0 \cdot 22 \\
0.07 \\
0.04\end{array}$ \\
\hline Cathode. & $\begin{array}{c}\text { immediately. } \\
3 \\
4\end{array}$ & $\begin{array}{r}10 \cdot 3 \\
9 \cdot 6 \\
9 \cdot 1\end{array}$ & $\begin{array}{l}0.5 \\
0.8 \\
1.0\end{array}$ \\
\hline Anode. & $\begin{array}{r}9 \\
19\end{array}$ & $\begin{array}{l}11.8 \\
11.9\end{array}$ & $\begin{array}{l}0.09 \\
0.06\end{array}$ \\
\hline
\end{tabular}

In the next experiment also sodium carbonate solution was used, and after the current had fallen to 0.07 ampere, part of the sodium carbonate solution was replaced by a saturated solution of potassium chloride. The current increased steadily, after 60 minutes it was 0.35 ampere. On reversal, the current rose immediately to over 2 amperes.

In a similar experiment, after the current had fallen to 0.08 ampere, half of the sodium carbonate solution was removed, and a saturated solution of potassium sulphate added; even after 60 minutes there was no change in the current. Ammonia was also used in the inner cell, and half of it replaced by saturated solution of potassium sulphate after the current had decreased to 0.04 ampere. After 60 minutes the current was 0.05 ampere, and after 20 hours it was constant at $0 \cdot 10$ ampere. On reversal it immediately rose to over 2 amperes.

An experiment was also made with solutions of sodium carbonate and aluminium chloride. In this case, after the current had fallen to 0.05 ampere, the poles were reversed and the current increased rapidly (to 0.6 ampere in 1.5 minute); but on again reversing, it quickly diminished to its former value.

There is still another way in which the explanation might be tested-by direct measurement of the resistance which the film offers to the passage of different ions. Suppose that solutions of the four salts $\mathrm{Al}_{2}\left(\mathrm{SO}_{4}\right)_{3}, \mathrm{AlCl}_{3}, \mathrm{~K}_{2} \mathrm{SO}_{4}, \mathrm{KCl}$, be prepared so that they have the same conductivity at say $25^{\circ} \mathrm{C}$., and that now the two electrodes be separated by a film of $\mathrm{Al}(\mathrm{OH})_{3}$; then the resistances depend upon the rapidity with which the ions can pass through the film, and the four solutions will, in this case, bave different conductivities. The differences should, moreover, be of quite a high order. Phil. Mag. S. 6. Vol. 5. No. 27. March $1903 . \quad$ Y 
For in the case of $\mathrm{Al}_{2}\left(\mathrm{SO}_{4}\right)_{3}$, neither ion would pass through the film, and the resistance measured should be high ; in the case of $\mathrm{AlCl}_{3}$, and of $\mathrm{K}_{2} \mathrm{SO}_{4}$, only one ion could pass through, and the resistances should be of the same order, though much smaller than in the first case. The presence of the film should not make much difference to the resistance of the $\mathrm{KCl}$ solution, since both ions can pass through; this solution should, therefore, have the smallest resistance.

The apparatus which we used consisted of two glass tubes with flanges ground to fit one another. Between the two tubes was placed a piece of filter-paper which had been soaked in a dilute gelatine solution. The flanges were pressed together while the gelatine was hot, so that a close and water-tight junction was made. Dilute solution of aluminium sulphate was poured into one tube which was closed with a rubber stopper provided with an overflow tube; the apparatus was then reversed and a dilute solution of ammonia was poured into the other tube. In this way a film of $\mathrm{Al}(\mathrm{OH})_{3}$ was formed in the gelatinized paper, and after a few hours the whole was carefully washed out with distilled water. One tube was then filled with the solution to be examined, the corresponding electrode adjusted to a definite mark - an overflow tube preventing rupture of the film; the apparatus was then reversed and the other tube filled with the same solution, and the electrode inserted. The whole was placed in a thermostat at $25^{\circ} \mathrm{C}$. and measurements of the resistance made. They were as follows :-

$$
\begin{array}{ll}
\mathrm{Al}_{2}\left(\mathrm{SO}_{4}\right)_{3} & 289 \text { ohms } \\
\mathrm{AlCl} & 259 \text { ohms } \\
\mathrm{KCl} & 248 \text { ohms. }
\end{array}
$$

These differences are very small, especially as we found the error of adjustment of the electrodes to be considerable.

Fig. 1.

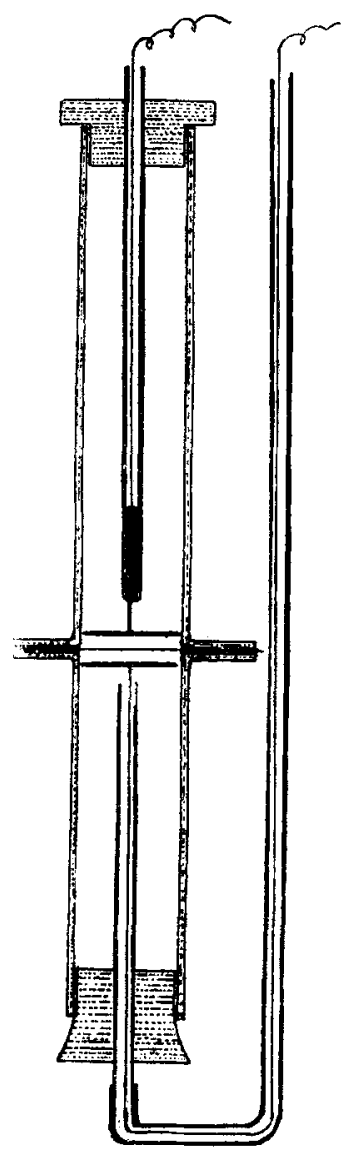

It is doubtful if it is practicable to determine these differences 
with an alternating current. There can be no migration of the ions (with a high frequency and small current), and therefore a very small amount of certain salts in the film is sufficient to enable a current to pass; and will, in fact, largely determine the conductivity. Now the formation of the film by the interaction of the two salts necessarily produces such a salt in the film; and this, no doubt, is very difficult to remove completely by mere washing *

We propose therefore to repeat the experiments with a more suitable arrangement of electrodes, and with special preparation of the film. We also hope to make measurements of the resistances using continuous currents.

The explanation of the peculiarities of aluminium when used as an anode in solutions of sulphates, which has thus been suggested, may be applied to the phenomena observed in the reaction between aluminium and dilute acids. But it seemed desirable to determine by experiment whether the presence of those ions which have so marked an influence on the anode has a similar influence on the rate of solution of aluminium in sulphuric acil. Accordingly, the following rough determinations were made of the rate of evolution of hydrogen from the acid, both alone, and with addition of certain ions.

Preliminary trial showed that at temperatures of $80^{\circ} \mathrm{C}$. to $85^{\circ} \mathrm{C}$., and with a 2-molar solution of sulphuric acid, the reaction proceeded at a rate which could be conveniently measured. A thermostat was adjusted to $85^{\circ} \mathrm{C}$, and all the experiments were made at this temperature. Small flasks of about 80 c.c. capacity, and pieces of sheet aluminium of uniform size and weight $(25 \mathrm{~mm}$. square, $0.45 \mathrm{gm}$.) were used. Each flask contained one piece of the metal and 60 c.c. of a 2 -molar sulphuric acid solution, and in addition a known quantity of a concentrated solution of the salt under investigation. 'The gas evolved was collected in a burette. The salts employed were $\mathrm{KCl}, \mathrm{KBr}, \mathrm{KNO}_{3}$, and KCNS. The results are summarized below.

Chloride.-Four experiments were made to determine the effect of chloride, a 3.9 molar solution of potassium chloride

* With a direct current this sait is removed from the film by the action of the current. This is probably the reason why, in the series of experiments last described, the current at first is so long (20 hours) in reaching a minimum, although afterwards it reaches the same minimum in much less time (about the same time that had elapsed between the two previous commutations). 
being used. The intervals of time required for the evolution of 50 c.c. of hydrogen were

(1) 60 c.c. acid. 180 minutes, diminishing to 150 minutes.

(2) 60 c.c. acid +1 c.c. $\mathrm{KCl} . \quad 70$ minutes, diminishing to

(3) 60 c.c. acid +2 c.c. $\mathrm{KCl} . \quad 2$ minutes.

(4) 60 c.c. acid +4 c.c. $\mathrm{KCl} .25$ minutes, diminishing to 1.7 minute.

These figures show that chloride has a very decided influence on the velocity of the reaction, but it does not seem to play the part of a simple catalysator. One noticeable feature is that when 2 c.c. of the solution have been added, its maximum effect has been almost reached.

The action may be explained as follows--when a piece of aluminium is put into dilute sulphuric acid, it is covered with a film of hydroxide; this film, being impermeable to $\mathrm{SO}_{4}{ }^{\prime \prime}$ ions, is impermeable to $\mathrm{H} \cdot$ ions also, for the one ion cannot go anywhere without the other. Thus there is no action between the metal and the acid. The aluminium, however, acts slowly on the water in the film, forming hydrogen and aluminium hydroxide, which maintains the continuity of the film. In this way a slow continuous action takes place. If potassium chloride be added to the acid, $\mathrm{H} \cdot$ ions can permeate the membrane, for the $\mathrm{Cl}^{\prime}$ ions can go with them, and the metal thus comes in contact with $\mathrm{H}$ - ions. This action breaks up the film and so admits the sulphuric acid to the surface of the metal.

If the concentration of $\mathrm{Cl}^{\prime}$ ions is too small to cause violent action and so destroy the film, they will still have an accelerating influence, but the maximum effect will not be attained.

Bromide.-Addition of bromide appears to have very little influence on the velocity of reaction. Four experiments were made, a 4-molar solution of potassium bromide being used. The times of evolution of 50 c.c. of hydrogen were
(1) 60 c.c. acid
(2) 60 c.c. acid +2 c.c. $\mathrm{KBr}$.
(3) 60 c.c. acid +4 c.e. $\mathrm{KBr}$.
(4) 60 c.c. acid (no. 1$)+1$ c.c. $\mathrm{KBr}$.
150 minutes. $160 \%$ $155 "$ $140 \quad "$

The fourth experiment was made with the aluminium and acid already used in experiment (1), in order to remove uncertainty as to the uniformity of the surface. Hence the influence of bromide is very slight and the experiments are not sufficient to show whether it accelerates or retards the reaction. 
Nitrate and Thiocyanate.-These salts were found to have an accelerating effect. With nitrate the reaction was somewhat irregular, and the gas evolved was found to contain nitric oxide. In the case of thiocyanate, hydrogen sulphide was produced in considerable quantity. The results, consequently, are of no value.

Finally, two experiments were made, with acetic acid, and with a mixture of acetic acid and potassium chloride; for according to the theory, presence of chloride should have an accelerating effect. The acetic acid solution was that of maximum conductivity, and the potassium chloride solution was 3.9 molar. The action was very slow and the curves obtained were irregular. In 30 hours 18 c.c. of hydrogen were erolved when acetic acid alone was used, and in the same time 22 c.c. of hydrogen with a mixture of 2 c.c. KCT and 60 c.c. of acetic acid.

These experiments must be regarded as rough preliminary observations, and we wish to return to the subject at a later date.

\section{Summary.}

1. The influence of chloride, bromide, nitrate, acetate, chlorate, and thiocyanate, in varying concentration, on an aluminium anode in sulphuric acid was investigated.

2. A theory to explain the results was brought forward and tested experimentally.

3. The essential peculiarities of an aluminium anode were reproduced by means of a platinum anode and a film of aluminium hydroxide.

4. Some mensurements were made to determine the influence of chloride and of bromide, on the reaction between aluminium and sulphuric acid.

Chemical Laboratory,

University of Edinburgh. October 1902.

XXX. On Loaded Lines in Telephonic Transmission. By George A. Campbeli *

[Plates V. \& VI.]

THE loaded line discussed in this paper is an electrical circuit of two long parallel conducting wires having self-induction coils inserted at regular intervals. An elementary mathematical treatment adapted to engineering

* Communicated by Prof. Trowbridge. 